\title{
BEBAN PERAWATAN PADA KELUARGA DENGAN PENDERITA GANGGUAN JIWA DI DESA KEBONSARI
}

\author{
Faida Annisa ${ }^{*}$ \\ ${ }^{1}$ Akademi Keperawatan Kerta Cendekia Sidoarjo \\ *Correspondence: \\ Faida Annisa \\ Email: nio_annisa@yahoo.com
}

\begin{abstract}
Keluarga penderita gangguan jiwa berat yang ada di Indonesia, terutama di Jawa Timur, telah memiliki sikap yang positif dan cukup baik dalam melakukan perawatan kepada anggota keluarganya yang menderita gangguan jiwa berat. Sikap tersebut terbangun dengan proses yang cukup lama sehingga mereka belajar untuk memahami dan mulai memberikan dukungan sosial kepada anggota keluarganya yang menderita gangguan jiwa berat. Selain itu, keluarga-keluarga dengan penderita gangguan jiwa berat ini masih memerlukan pertolongan dari petugas kesehatan guna memberikan informasi-informasi terkait dengan keadaan anggota keluarganya yang menderita gangguan jiwa
\end{abstract} berat tersebut.

Key words: Beban perawatan, penderita gangguan jiwa, keluarga

\section{PENDAHULUAN}

Gangguan jiwa berat, atau yang dikenal dengan sebutan psikosis (salah satu contoh psikosis adalah skizofrenia), adalah gangguan jiwa yang ditandai oleh terganggunya kemampuan menilai realitas atau tilikan (insight) yang buruk; gejala yang menyertai yaitu halusinasi, ilusi, waham, gangguan proses pikir, kemampuan berpikir, serta tingkah laku aneh (agresivitas atau katatonik); angka prevalensi gangguan jiwa berat di Indonesia yaitu 1.7 per mil (Kemenkes, 2013).

Pelayanan kesehatan tidak hanya berfokus di rumah sakit, tetapi juga di komunitas. Pada pasien gangguan jiwa yang telah mendapatkan perawatan di rumah sakit akan dikembalikan ke keluarga yang bertanggungjawab, sehingga perawatan pada pasien tetap berlanjut yang diberikan oleh keluarga dan masyarakat, serta tetap dalam pantauan petugas kesehatan di wilayah tersebut.

Akan tetapi, sebagai caregiver, keluarga sering mengalami kesulitan tidak hanya karena penderita mengalami keterbatasan dalam memenuhi kebutuhannya sehari-hari, juga perilaku psikotik yang muncul seperti teriak-teriak dan marah tanpa sebab, menarik diri dari lingkungan, berbicara atau tertawa sendiri, hingga melakukan tindakan kekerasan ke orang lain atau diri sendiri (American Psychiatric Association, 2013). 
Akademi Keperawatan Kerta Cendekia memiliki Desa Binaan yaitu Desa Kebonsari Kecamatan Candi Kabupaten Sidoarjo. Mahasiswa Semester V Tahun Akademik 2016/2017 melaksanakan Praktek Klinik Keperawatan Komunitas dan Keluarga di desa tersebut selama 1 bulan. Selama menjalani praktek klinik, masing-masing mahasiswa melakukan asuhan keperawatan keluarga kepada 1 keluarga binaan. Terdapat 6 keluarga yang memiliki penderita gangguan jiwa di wilayah RW II, dan menjadi keluarga binaan mahasiswa. Keluarga binaan dengan penderita gangguan jiwa menjadi salah satu fokus asuhan keperawatan keluarga yang diberikan oleh Akademi Keperawatan Kerta Cendekia.

\section{BEBAN PERAWATAN KELUARGA}

Dari hasil wawancara dan observasi dengan menggunakan kuesioner pada 6 keluarga dengan penderita gangguan jiwa, didapatkan data yang menunjukkan beberapa faktor beban perawatan pada keluarga yang merawat penderita gangguan jiwa di rumah.

\section{Data Demografi}

Data demografi penderita gangguan jiwa dan keluarga yang merawat dicatat dalam lembar observasi.

Berdasarkan data demografi penderita gangguan jiwa, didapatkan sebagai berikut: usia penderita paling muda adalah 35 tahun (17\%), dan paling tua 66 tahun (17\%), laki-laki sebanyak 4 orang (67\%), yang belum berkeluarga sebanyak 4 orang (67\%), lulusan SMA sebanyak 3 orang $(50 \%)$, tidak bekerja sebanyak 4 orang (67\%), lama mengalami gangguan jiwa rata-rata 14 tahun, dan dirawat di rumah sakit jiwa rata-rata 2 kali.
Data demografi yang didapatkan pada keluarga yang merawat penderita gangguan jiwa sebagai berikut: rerata usia adalah 55 tahun, paling banyak adalah wanita sebanyak 5 orang $(83 \%)$, yang sudah berkeluarga 4 orang (67\%), lulus SD sebanyak 3 orang (50\%), tidak bekerja sebanyak 3 orang (50\%), dan yang berperan sebagai orang tua dari penderita gangguan jiwa sebanyak 3 orang (50\%).

\section{Penilaian Perilaku Gangguan Jiwa}

Penilaian perilaku gangguan jiwa menggunakan kuesioner The Psychiatric Behavior and Symptom Perception Scale (PBSPS) yang dibuat oleh Pipatananond (2001), dan sudah pernah digunakan dalam penelitian dengan responden keluarga yang merawat pasien skizofrenia di Surabaya, Indonesia (Annisa, 2015).

Penderita gangguan jiwa mungkin akan mengalami periode akut selama berada di rumah. Keluarga menilai rerata perilaku gangguan jiwa pada anggotanya dalam beberapa minggu terakhir yaitu 26.00 (0-87). Perilaku gangguan jiwa tersebut terdiri dari lima kategori, yaitu penampilan yang tidak sesuai, gejala depresi, gejala psikotik, kesulitan berkonsetrasi dan memori, dan perilaku adiktif. Berikut ini rerata yang dinilai oleh keluarga berdasarkan kategori, yaitu penampilan yang tidak sesuai didapatkan 9.33 (0-30), gejala depresi 5.17 (0-21), gejala psikotik 5.83 (0-15), kesulitan berkonsentrasi dan memori 4.17 (0-12), dan perilaku adiktif 1.50 (0-9). Hal ini menunjukkan perilaku penderita yang menunjukkan gangguan jiwa saat di rumah tidak begitu parah menurut keluarga yang merawat. 


\section{Pengetahuan tentang Gangguan Jiwa Berat}

Untuk mengetahui tingkat pengetahuan keluarga tentang gangguan jiwa berat menggunakan kuesioner dari National Alliance on Mental Illness (NAMI) yang pernah digunakan pada penelitian dengan responden keluarga yang merawat pasien skizofrenia di Surabaya, Indonesia (Annisa, 2015).

Berdasarkan kuesioner yang diberikan, sebanyak 7 pertanyaan mengenai pengertian gangguan jiwa berat, penyebab, tanda dan gejala, dan penanganannya, didapatkan 3 orang yang menjawab 2 soal dengan benar, dan 1 orang menjawab 3 soal dengan benar (Mean 1.67, 0-7). Hal ini menunjukkan kurangnya pengetahuan keluarga tentang gangguan jiwa berat, sehingga sangat membutuhkan informasi dan pendidikan kesehatan agar dapat membantu keluarga dalam menerima dan merawat anggotanya yang mengalami gangguan jiwa dengan optimal.

\section{Sikap terhadap Gangguan Jiwa Berat}

Tingkat pengetahuan seseorang dapat mempengaruhi sikapnya akan hal tersebut. Keluarga juga diberikan kuesioner mengenai sikap terhadap gangguan jiwa berat, dan didapatkan rerata 23.33 (9-45). Sikap terhadap gangguan jiwa berat diklasifikasikan menjadi aspek kognitif, aspek afektif, dan aspek perilaku. Berikut ini nilai rerata yang didapatkan dari keluarga: aspek kognitif 7.17 (3-15), aspek afektif 7.17 (3-15), dan aspek perilaku 9.00 (3-15). Hal ini menunjukkan sikap keluarga terhadap gangguan jiwa cukup baik, mereka menerima anggotanya dengan kasih sayang walaupun masih ada stigma dari masyarakat.

\section{Pengalaman Positif dalam Perawatan}

Pengalaman positif yang dirasakan keluarga dalam memberikan perawatan ke penderita dengan gangguan jiwa dikaji dengan menggunakan kuesioner Attitudes Towards Schizophrenia Questionnaire (ATSQ) yang pernah digunakan pada penelitian dengan responden keluarga yang merawat pasien skizofrenia di Surabaya, Indonesia (Annisa, 2015).

Keluarga telah merawat penderita dalam waktu yang lama dan minim akan bantuan, sehingga mampu belajar meningkatkan kemampuan dalam merawat berdasarkan pengalaman yang didapat. Hal ini nampak pada hasil kuesioner mengenai pengalaman positif dalam memberikan perawatan yaitu rerata 171.00 (44-220). Pengalaman positif ini terbagi menjadi empat kategori yaitu aspek pengembangan diri, aspek motivasi peran, aspek konsep diri dan sosial, dan aspek kepuasan peran. Berikut ini nilai rerata masing-masing aspek tersebut, yaitu aspek pengembangan diri 52.17 (14-70), aspek motivasi peran 50.50 (13-65), aspek konsep diri dan sosial 34.33 (9-45), dan aspek kepuasan peran 30.33 (8-40).

\section{Sumber Dukungan Sosial}

Sumber dukungan sosial keluarga dikaji dengan kuesioner The PRQ2000 yang pernah digunakan pada penelitian dengan responden keluarga yang merawat pasien skizofrenia di Surabaya, Indonesia (Annisa, 2015).

Dukungan sosial yang didapat oleh keluarga cukup besar, ini terlihat pada hasil rerata dari kuesioner yaitu 74.50 (15-105). Hal ini menunjukkan keluarga di Indonesia, terutama di Jawa Timur, sangat dekat dan peduli, sehingga jika ada masalah atau 
membutuhkan bantuan mereka selalu siap mendampingi dan memberikan dukungan.

\section{Beban Perawatan}

Beban perawatan keluarga dengan penderita gangguan jiwa dikaji dengan kuesioner Burden Assessment Schedule (BAS) yang pernah digunakan pada penelitian dengan responden keluarga yang merawat pasien skizofrenia di Surabaya, Indonesia (Annisa, 2015).

Lima dalam enam keluarga (83\%) mengalami beban dalam merawat anggota keluarganya yang mengalami gangguan jiwa. Kuesioner beban perawatan ini terdiri dari aspek apresiasi terhadap peran perawatan, dampak terhadap perasaan nyaman, beratnya masalah gangguan yang dihadapi, dampak terhadap hubungan dengan orang lain, dan dampak terhadap kualitas hubungan. Berikut ini masingmasing nilai rerata dari aspek tersebut, yaitu aspek apresiasi terhadap peran perawatan 7.33 (4-12), aspek dampak terhadap perasaan nyaman 7.33 (4-12), aspek beratnya masalah gangguan yang dihadapi 6.83 (4-12), aspek dampak terhadap hubungan dengan orang lain 6.50 (4-12), dan aspek dampak terhadap kualitas hubungan 1.50 (4-12).

\section{SARAN}

Keluarga yang merawat penderita gangguan jiwa di rumah merupakan "secondary patient" bagi petugas kesehatan (Reinhard, 2008), karena mereka juga membutuhkan perhatian dan pelayanan berupa informasi, pendidikan kesehatan, dan berbagai metode untuk meningkatkan kemampuannya dalam merawat penderita gangguan jiwa di rumah dengan optimal tanpa mempengaruhi kesehatan fisik dan mental mereka sendiri (National Alliance for Caregiving, 2010).

Keluarga dengan penderita gangguan jiwa tidak akan mampu merawat anggotanya tanpa adanya pertolongan dan dukungan dari masyarakat dan perangkat desa. Dukungan sosial yang kuat terbukti dapat menurunkan tingkat beban perawatan yang dialami keluarga. Permasalahan yang dihadapi dalam merawat penderita gangguan jiwa juga akan lebih mudah diselesaikan dengan adanya bantuan dari perangkat desa, terutama dalam hal pengurusan administrasi di institusi pelayanan

\section{DAFTAR PUSTAKA}

1. Annisa, F. (2015). Predicting Factors of Burden Among Family Caregivers of Patients with Schizophrenia in Surabaya, Indonesia. Thai Pharmateutical Health Science Journal, 10(3), 87-97.

2. American Psychiatric Association [APA]. (2013). Diagnostic and statistical manual of mental disorders, DSM-5 ( $5^{\text {th }}$ ed.). Washington, DC: APA.

3. Kementerian Kesehatan Republik Indonesia. (2013). Penyajian PokokPokok Hasil Riset Kesehatan Dasar 2013. Retrieved from www.litbang.depkes.go.id.

4. National Alliance for Caregiving [NAC]. (2010). Care for the family caregiver: A place to start. Retrieved from http://www.caregiving.org/data/Emble m_CfC10_Final2.pdf.

5. Reinhard, S. C., Given, B., Petlick, N. H., \& Bemis, A. (2008). Chapter 14: Supporting family caregivers in providing care. In Hughes, R. G. (Ed.), 
Patient safety and quality: An evidencebased handbook for nurses (AHRQ Publication No. 08-0043, pp. 1-64). Rockville, MD: Agency for Healthcare Research and Quality.

Cite This Article As: Annisa, F. Beban Perawatan Pada Keluarga Dengan Penderita Gangguan Jiwa Di Desa Kebonsari. Nurse and Health: Jurnal Keperawatan 2018; 7(1): 8-12. 